\title{
Development and Characterization of Solid-Lipid Microparticles of Highly Insoluble Drug Sirolimus
}

Basavaraj K. Nanjwade*, Didhija J. Patel, Kemy A. Parikh, Veerendra K. Nanjwade and F. V. Manvi

Department of Pharmaceutics, KLE University College of Pharmacy, Belgaum, India

\begin{abstract}
Solid lipid microparticles (SLMs) represent an alternative carrier system to traditional colloidal carrier such as emulsion, liposomes and polymeric micro and nanoparticles. The purpose of this research work was to develop and evaluate solid lipid microparticles of sirolimus for oral delivery. Sirolimus is an immunosupressive drug used to prevent transplant rejection and to treat auto immune diseases. It is a macrolide lactone produced by streptomyces hydroscopicus. It is extremely hydrophobic. Sirolimus solid lipid microparticles were prepared by hot homogenization technique. The matrix chiefly consisted of glyceryl monostearate and sodium taurocholate. The SLMs were studied for its particle size analysis, drug content, entrapment efficiency, in vitro release characteristics and also for stability analysis at different temperature and humidity conditions. Average particle size was found to be $21.40 \mu \mathrm{m}$. Drug content of SLMs determined by HPLC analysis was found to be $98.6 \pm 0.31 \%$ while entrapment efficiency achieved was $98.02 \%$. Drug release from the final formulation was found to be $90.3 \%$ in $90 \mathrm{~min}$. SLMs formulated with glyceryl monostearate and sodium taurocholate can be used for oral delivery of hydrophobic drugs with in-vivo study still to be explored.
\end{abstract}

Keywords: Sirolimus; Immunosuppressant; Solid lipid microparticulates; Hot homogenization technique; Biocompatible lipid microparticles; Glyceryl monostearate

\section{Introduction}

Sirolimus (Rapamycin, Rapammune) is a macrolide lactone produced by streptomyces hydroscopicus. It is an immunosupressive agent used for the prophylaxis of renal allograft rejection. The drug was first isolated from a soil sample from Rapa Nui, an island in the south pacific, hence the prefix "Rapa". It is extremely hydrophobic having molecular weight $914.2 \mathrm{~g} / \mathrm{mol}[1,2,3]$. Sirolimus is neither calcineurin inhibitor (as are cyclosporine and tacrolimus) nor an anti metabolite (as are mycophenolate mofetil and azathioprine). Sirolimus has a novel mechanism of immunosuppressant action involving the suppression of T-lymphocyte proliferation through inhibition of the target of rapamycin protein kinase complex (TORC) [4]. Mammalian TORC is critical for cell cycle progression and cell proliferation. Blockade of TORC inhibits cytokine-mediated proliferation in T cells, B cells and mesenchymal cells, including smooth muscle cells [5].

In recent years, biocompatible lipid micro- and nanoparticles have been reported as potential drug carrier systems as alternative materials to polymers [6]. They can be considered as physiologically compatible, physicochemically stable and allowing a large-scale production at a relative low production cost than liposomes [7]. These micrometer-sized particles consist of a solid fat core based on naturally occurring lipids and stabilized by a layer of surfactant molecules on the surface [8]. SLM are characterized by their better bio-compatibility as compared to competing polymeric microparticles [9]. Solid lipid micro- or nanoparticles are in the form of solid lipids and provide an alternative option for encapsulating lipophilic compounds. Protein stabilization could be achieved by a suitable particle formulation or a polymer mixture [10]. Different methods can be adopted to prepare solid lipid micro- or nanoparticles. In one of the study, modified high shear homogenization and ultrasound method was utilized to formulate SLNs [11]. Reithmeier H and co- workers [12,13] in two different studies prepared peptide containing glyceryl palmitate microparticles as well as lipid microparticles by using modified solvent evaporation method and a melt dispersion technique without the use of organic solvent.
In this study, we prepared solid lipid microparticles by hot homogenization method [14,15]. The main aim of this investigation was to develop and evaluate solid lipid microparticles of sirolimus for oral delivery. The proposed sirolimus concentration in this formulation was chosen after assay and moisture content correction of API (sirolimus). Furthermore, in the present investigation, we aimed at fabricating SLM of sirolimus by using hot homogenization method and with easily available solid lipids such as glyceryl monostearate (GMS) and characterized it for assay and in vitro release.

\section{Materials and Methods}

\section{Materials}

Sirolimus (Zydus Cadila, Ahmedabad); Glyceryl monostearate (Fine organics Ltd., Mumbai, India); Sodium taurocholate, Acetone, Ethanol (All AR grade) and Acetonitile (ACN), $\mathrm{H}_{3} \mathrm{PO}_{4}$ (HPLC grade) were purchased from S.D. fine chemicals (Mumbai, India). All the excipients and reagents were used as received. Double distilled water was prepared freshly when ever required.

\section{Preparation of solid lipid microparticles}

Solid lipid microparticles were prepared by a hot homogenization technique. The formulations were optimized by first preparing blank microparticles by varying the content of GMS and sodium taurocholate and also by varying the processing parameters as shown in Table 1 and 2. Blank SLMs were prepared by first dissolving GMS in a mixture

*Corresponding author: Dr. Basavaraj K. Nanjwade, Department of Pharmaceutics, KLE University College of Pharmacy, BELGAUM, INDIA - 590010, Tel: 00919742431000; Fax: 00918312472387; E-Mail: bknanjwade@yahoo.com

Received December 07, 2010; Accepted January 24, 2011; Published February 01, 2011

Citation: Nanjwade BK, Patel DJ, Parikh KA, Nanjwade VK, Manvi FV (2011) Development and Characterization of Solid-Lipid Microparticles of Highly Insoluble Drug Sirolimus. J Bioequiv Availab 3: 011-015. doi:10.4172/jbb.1000050

Copyright: (c) 2011 Nanjwade BK, et al. This is an open-access article distributed under the terms of the Creative Commons Attribution License, which permits unrestricted use, distribution, and reproduction in any medium, provided the original author and source are credited. 


\begin{tabular}{|c|c|c|c|c|c|c|}
\hline Ingredients & LIPO F/P 8001 & LIPO F/P 8002 & LIPO F/P 8003 & LIPO F/P 8004 & LIPO F/P 8005 & LIPO F/P 8006 \\
\hline Glyceryl mono stearate & $2.44 \mathrm{~g}$ & $2.44 \mathrm{~g}$ & $2.44 \mathrm{~g}$ & $2.44 \mathrm{~g}$ & $5 \mathrm{~g}$ & $5 \mathrm{~g}$ \\
\hline Sodium tauro cholate & $0.1 \% \mathrm{w} / \mathrm{v}$ & $0.2 \% \mathrm{w} / \mathrm{v}$ & $0.3 \% \mathrm{w} / \mathrm{v}$ & $0.1 \% \mathrm{w} / \mathrm{v}$ & $0.2 \% \mathrm{w} / \mathrm{v}$ & $0.2 \% \mathrm{w} / \mathrm{v}$ \\
\hline Acetone & $5 \mathrm{ml}$ & $5 \mathrm{ml}$ & $5 \mathrm{ml}$ & $5 \mathrm{ml}$ & $2 \mathrm{ml}$ & $2 \mathrm{ml}$ \\
\hline Ethanol & $5 \mathrm{ml}$ & $5 \mathrm{ml}$ & $5 \mathrm{ml}$ & $5 \mathrm{ml}$ & $2 \mathrm{ml}$ & $2 \mathrm{ml}$ \\
\hline PVA solution & $150 \mathrm{ml}$ & $150 \mathrm{ml}$ & $150 \mathrm{ml}$ & - & - & - \\
\hline Water & - & - & - & $200 \mathrm{ml}$ & $250 \mathrm{ml}$ & $250 \mathrm{ml}$ \\
\hline Mannitol & - & - & - & - & - & $2.5 \mathrm{~g}$ \\
\hline
\end{tabular}

Table 1: Formulation table for blank SLM formulations.

\begin{tabular}{|c|c|c|c|c|}
\hline Formulation & Homogenization & Stirring time and speed & Centrifugation & Lyophilization \\
\hline Lipo F/P 8001 & - & $30 \mathrm{~min}, 500 \mathrm{rpm}$ & - & - \\
\hline Lipo F/P 8002 & - & $30 \mathrm{~min}, 500 \mathrm{rpm}$ & - & - \\
\hline Lipo F/P 8003 & - & $60 \mathrm{~min}, 500 \mathrm{rpm}$ & - & - \\
\hline Lipo F/P 8004 & $12,000 \mathrm{rpm}, 2-3 \mathrm{~min}$ & $60 \mathrm{~min}, 500 \mathrm{rpm}$ & - & - \\
\hline Lipo F/P 8005 & $16,000 \mathrm{rpm}, 2-3 \mathrm{~min}$ & $60 \mathrm{~min}, 700 \mathrm{rpm}$ & - & $-25^{\circ} \mathrm{C}, 5.0 \mathrm{~Pa}$ for $17 \mathrm{hrs}$ \\
\hline Lipo F/P 8006 & $19,000 \mathrm{rpm}, 2-3 \mathrm{~min}$ & $\begin{array}{l}\text { 90min,1000rpm } \\
90 \mathrm{~min}, 1500 \mathrm{rpm}\end{array}$ & $5000 \mathrm{rpm}, 10^{\circ} \mathrm{C}, 10 \mathrm{~min}$ & $\begin{array}{l}-25^{\circ} \mathrm{C}, 5.0 \mathrm{~Pa} \\
\text { For } 17 \mathrm{hrs}\end{array}$ \\
\hline
\end{tabular}

Table 2: Processing variables for blank SLM formulations.

\begin{tabular}{|c|c|}
\hline Bank SLM Formulations & Observation \\
\hline Lipo F/P 8001 & $\begin{array}{l}\text { - Very less amount of SLMs were observed. } \\
\text { - } \text { Crystals were formed. } \\
\text { - } \quad \text { After 2-3 days SLMs were disappeared. }\end{array}$ \\
\hline Lipo F/P 8002 & $\begin{array}{l}\text { - Very less amount of SLMs were observed. (but amount of SLMs were more in Lipo F/P } 8002 \text { than Lipo F/P 8001). } \\
\text { - Crystals were formed. } \\
\text { - Physically Unstable formulation. } \\
\text { - After 2-3 days SLMs were disappeared }\end{array}$ \\
\hline Lipo F/P 8003 & $\begin{array}{l}\text { - Very less amount of SLMs were observed.(amount of SLMs were very less in Lipo F/P } 8003 \text { than Lipo F/P } 8001 \text { and Lipo F/P } 8002) \text {. } \\
\text { - Crystals were formed. } \\
\text { - Physically Unstable formulation. } \\
\text { - }\end{array}$ \\
\hline Lipo F/P 8004 & $\begin{array}{l}\text { - Amount of SLMs were more than Lipo F/P } 8001,2,3 \text { observed. } \\
\text { - Fewer amounts of crystals were formed. } \\
\text { - Physically Unstable formulation. } \\
\text { - After } 10 \text { days SLMs were disappeared }\end{array}$ \\
\hline LipoF/P 8005 & $\begin{array}{l}\text { - Satisfactory amounts of SLMs were observed. } \\
\text { - Fewer amounts of crystals were formed. } \\
\text { - Physically stable formulation. }\end{array}$ \\
\hline Lipo F/P 8006 & $\begin{array}{l}\text { - Higher amounts of SLMs were observed. (more than Lipo F/P 8005) } \\
\text { - Crystals were not formed. } \\
\text { - Physically stable formulation. }\end{array}$ \\
\hline
\end{tabular}

Table 3: Observation of different trials of blank SLMs.

of acetone and ethanol (1:1). Organic solvents were completely removed using Buchi rotoevaporator (Buchi Laboretechnik AG, Flawil, Switzerland). Lipid layer was melted by heating $5^{\circ} \mathrm{C}$ above the melting point of lipid. An aqueous phase was prepared by dissolving sodium taurocholate in double distilled water and heating to the same temperature as the oil phase. The hot aqueous phase was added to the oil phase, and homogenization was performed using Ultra Turrax high speed homogenizer for 2-3 min. Obtained micro emulsion was immediately dispersed in cold water $\left(2-3^{\circ} \mathrm{C}\right)$, under mechanical stirring. After a certain period, the samples were centrifuged at $10^{\circ} \mathrm{C}$, $5000 \mathrm{rpm}$ for $10 \mathrm{~min}$. Obtained micro emulsion was then lyophilized using Virtis ADVANTAGE, Wizard 2.0 Lyophilizer and obtained lyophilized powder was further evaluated. From the results obtained, blank formulation Lipo F/P 8006 was selected for final drug loaded SLM formulation (Table 3 and 4). Drug loaded SLMs were prepared by dissolving the sirolimus and GMS in a mixture of acetone and ethanol and the same method was followed as for the blank preparation.

\section{Particle size analysis}

Particle size of the SLMs was determined immediately after dispersion, $1 \mathrm{~h}$ later, and after $17 \mathrm{~h}$. The oily dispersible solution was resuspended in distilled water, prior to particle size determination. In a typical experiment, $150 \mu \mathrm{l}$ of the oily solution was mixed in $5 \mathrm{ml}$ distilled water at $37^{\circ} \mathrm{C}$, using vortex for $30 \mathrm{~s}$. Then the particle size of the obtained suspension was determined at $37^{\circ} \mathrm{C}$ for 200 s by a Coulter N4 MD submicron particle size analyzer.

\section{Assay (By HPLC)}

Standard Preparation procedure: $25 \mathrm{mg}$ of sirolimus pure sample was accurately weighed and dissolved in $100 \mathrm{ml}$ of acetonitrile. $4 \mathrm{ml}$ of the above stock solution was then diluted in $25 \mathrm{ml}$ of acetonitrile to obtain a concentration of $40 \mu \mathrm{g} / \mathrm{ml} .20 \mu \mathrm{l}$ of this standard solution was injected by Hamilton $100 \mu \mathrm{l}$ syringe. The response of the preparation in terms of area under the two major peaks corresponding to isomer-C, Sirolimus standard was measured.

Sample preparation procedure: 10 capsules containing lyophilized powder of sirolimus lipospheres equivalent to $10 \mathrm{mg}$ of drug was taken in $250 \mathrm{ml}$ of volumetric flask and $150 \mathrm{ml}$ of acetonitrile was added to it. It was then sonicated and volume was made up to $250 \mathrm{ml}$ with acetonitrile. The solution was filtered with $0.45 \mu$ filter paper and filled in the HPLC and measured for assay.

1. Mobile phase: $0.01 \% \mathrm{H}_{3} \mathrm{PO}_{4}: \mathrm{ACN}(1: 1)$

2. Column: Kromasil/ $\mathrm{C}_{18}(150 \mathrm{~mm} \times 4.6 \mathrm{~mm}) 5 \mu \mathrm{m}$.

3. Flow rate: $2.0 \mathrm{ml} / \mathrm{min}$

4. Detector: $277 \mathrm{~nm}$

5. Column temperature: $50^{\circ} \mathrm{C}$

6. Sample cooler: $15^{\circ} \mathrm{C}$

7. Injection volume: $20 \mu \mathrm{l}$

8. Retention time: Sirolimus - $11.5 \mathrm{~min}$, Isomer C - $12.2 \mathrm{~min}$ 


\section{Entrapment efficiency}

The drug entrapment efficiency was determined by suspending known quantity of SLMs in methanol and stirring for few minutes. The free drug (unentrapped) which got dissolved in methanol was separated by centrifugation using a refrigerated centrifuge that runs for $10 \mathrm{~min}$ at $5000 \mathrm{rpm} / \mathrm{min}$. The obtained methanolic phase was filtered through a $0.8 \mu \mathrm{m}$ membrane filter. Then the filtrate was analyzed by HPLC. The drug entrapment efficiency (EE) of the SLM was calculated by the equation:

$$
E E(\%)=\left(\frac{W_{\text {initial drug }}-W_{\text {free drug }}}{W_{\text {initial drug }}}\right) \times 100
$$

Where $W_{\text {initial drug }}=$ Weight of drug added to the system, $W_{\text {free drug }}=$ Weight of free drug in the methanolic phase of system.

\section{In vitro drug dissolution studies}

Standard Preparation procedure: $25 \mathrm{mg}$ of Sirolimus pure sample was accurately weighed dissolved in $100 \mathrm{ml}$ of Acetonitrile. $2 \mathrm{ml}$ of the above stock was then diluted in $250 \mathrm{ml}$ of $0.4 \%$ SLS to obtain a concentration of $2 \mu \mathrm{g} / \mathrm{ml}$. $20 \mu \mathrm{l}$ of this standard solution was injected by Hamilton $100 \mu \mathrm{l}$ syringe. The response of the preparation in terms of area under the two major peaks corresponding to isomer-C, Sirolimus standard was measured.

Sample preparation procedure: In vitro dissolution was carried out by with USP type I apparatus using $500 \mathrm{ml}$ of $0.4 \%$ SLS as the dissolution medium. 1 capsule (Microspheres equivalent to $1 \mathrm{mg}$ of drug filled in each capsule) was placed in the each dissolution jar of the apparatus; dissolution was carried out at $120 \mathrm{rpm}$ at $37^{\circ} \mathrm{C}$ for $90 \mathrm{mins}$. Known volume of the samples were withdrawn at predetermined time intervals and filled in HPLC vials, replaced with the same amount of fresh medium.

1 Mobile phase: $0.01 \% \mathrm{H}_{3} \mathrm{PO}_{4}: \mathrm{ACN}(30: 70)$

2 Column: Kromasil/ $\mathrm{C}_{18} \quad(150 \mathrm{~mm} \times 4.6 \mathrm{~mm}) 5 \mu \mathrm{m}$.

3 Flow rate: $0.5 \mathrm{ml} / \mathrm{min}$

4 Detector: $277 \mathrm{~nm}$

5 Column temperature: $50^{\circ} \mathrm{C}$

6 Sample cooler: $15^{\circ} \mathrm{C}$

7 Injection volume: $20 \mu \mathrm{l}$

8 Retention time of sirolimus: $1 \mathrm{~min}$

\section{Scanning electron microscopy}

Scanning electron microscopy (SEM) is an electron optical imaging technique that provides photographic images and elemental information. SEM is useful for characterizing the morphology and size of microscopic specimens with particle size as low as $10^{-10}$ to 10 ${ }^{12} \mathrm{~m}$. The sample is placed in an evacuated chamber and scanned in a controlled pattern by an electron beam. Interaction of the electron beam with the specimen produces a variety of physical phenomena that, when detected, are used to form images and provide elemental information about the specimens.

Scanning electron microscopy (JSM 840 A) was used to study the surface morphology of the solid lipid microspheres. The samples were analyzed after they had been gold sputtered using $25 \mathrm{~nm}$ gold film thickness. Both samples were studied at magnifications at probe current of $20 \mathrm{KV}$.

\section{Short-term stability study}

Sirolimus solid lipid lipospheres were stored at temperature $2-8^{\circ} \mathrm{C}$, $25^{\circ} \mathrm{C} / 60 \% \mathrm{RH}$ and $40^{\circ} \mathrm{C} / 75 \% \mathrm{RH}$ for 30 days. Formulations at regular intervals were tested for physical changes, drug content and dissolution studies spectrophotometrically at $277 \mathrm{~nm}$.

\section{Results}

\section{Analytical method}

Linearity of sirolimus in acetonitrile by HPLC: A simple method of estimation was developed in acetonitrile at $277 \mathrm{~nm}$. The linearity of sirolimus is shown in Figure 1.

Development of HPLCestimation method for sirolimus: A precise, sensitive, reproducible High Performance Liquid Chromatographic method of estimation for sirolimus was developed. Further estimation of sirolimus was carried out by using newly developed HPLC method. A mixture of acetonitrile and $0.01 \%$ phosphoric acid (1:1) was used as a mobile phase on a $\mathrm{C}_{18}$ column. The flow rate was maintained at 2.0 $\mathrm{ml} / \mathrm{min}$. The peak height, area and retention time was calculated. The results are given in the Figure 2 and Table 5.

\section{Particle size analysis}

The effect of stirring speed on the properties of SLMs and the particle size distribution of SLMs is shown in Table 6 and 7 respectively.

\section{Drug content using HPLC}

Drug content of SLMs determined by HPLC analysis was found to be $98.6 \pm 0.31 \%(n=3)$

\begin{tabular}{|c|c|c|c|c|c|c|}
\hline \multicolumn{5}{|c|}{ Ingredients } & \multicolumn{2}{|c|}{ LIPO F 8006} \\
\hline \multicolumn{4}{|c|}{ Sirolimus } & \multicolumn{3}{|c|}{$101.10 \mathrm{mg}$} \\
\hline \multicolumn{5}{|c|}{ Glyceryl mono stearate } & \multicolumn{2}{|c|}{$5 \mathrm{~g}$} \\
\hline \multicolumn{5}{|c|}{ Sodium tauro cholate } & \multicolumn{2}{|c|}{$0.2 \% \mathrm{w} / \mathrm{v}$} \\
\hline \multicolumn{4}{|c|}{ Acetone } & \multicolumn{3}{|c|}{$2 \mathrm{ml}$} \\
\hline \multicolumn{4}{|c|}{ Ethanol } & \multicolumn{3}{|c|}{$2 \mathrm{ml}$} \\
\hline \multicolumn{4}{|c|}{ Water } & \multicolumn{3}{|c|}{$250 \mathrm{ml}$} \\
\hline \multicolumn{4}{|c|}{ Mannitol } & \multicolumn{3}{|c|}{$2.5 \mathrm{~g}$} \\
\hline \multicolumn{7}{|c|}{ Table 4: Sirolimus loaded SLM formulation. } \\
\hline No & \multicolumn{2}{|l|}{ Name } & \multicolumn{2}{|c|}{ Retention time(min) } & Area $\left(\mathrm{mcV}^{*} \mathbf{s}\right)$ & Area \% \\
\hline 1 & \multicolumn{2}{|c|}{ Sirolimus } & 11.458 & & 1698738 & 97.37 \\
\hline & \multicolumn{2}{|c|}{ Isomer-C } & 12.142 & & 45819 & 2.63 \\
\hline \multicolumn{5}{|c|}{ Total } & 1744557 & 100.00 \\
\hline \multicolumn{7}{|c|}{ Table 5: HPLC chromatogram parameters. } \\
\hline \multicolumn{2}{|c|}{ Formulation } & & ring speed (rpm) & \multicolumn{2}{|c|}{ Physical appearance } & Particle size $(\mu \mathrm{m})$ \\
\hline \multirow{2}{*}{\multicolumn{2}{|c|}{ Lipo F 8006}} & 10 & & \multirow{2}{*}{\multicolumn{2}{|c|}{$\begin{array}{l}\text { Microparticulates, } \\
\text { and free flowing } \\
\text { Agglomerated }\end{array}$}} & 21.40 \\
\hline & & 15 & & & & 40.20 \\
\hline
\end{tabular}

Table 6: Effect of stirring speed on properties of SLMs of sirolimus.

\begin{tabular}{|l|l|l|l|l|}
\hline $\begin{array}{l}\text { Particle size } \\
\text { range in } \boldsymbol{\mu m}\end{array}$ & $\begin{array}{l}\text { Midpoint size } \\
\text { (d) }\end{array}$ & Frequency(n) & (n.d) & $\begin{array}{l}\text { Average particle } \\
\text { size in } \boldsymbol{\mu m}\end{array}$ \\
\hline $0-10$ & 5 & 0 & 0 & \\
\hline $10-20$ & 15 & 56 & 840 & \\
\hline $20-30$ & 25 & 27 & 675 & \\
\hline $30-40$ & 35 & 15 & 525 & \\
\hline $40-50$ & 45 & 1 & 45 & \multirow{2}{*}{21.40} \\
\hline $50-60$ & 55 & 1 & 55 & \\
\hline $60-70$ & 65 & 0 & 0 & \\
\hline $70-80$ & 75 & 0 & 0 \\
\hline $80-90$ & 85 & 0 & 0 \\
\hline $90-100$ & 95 & 0 & 0 \\
\hline & & $\sum \mathrm{n}=100$ & $\begin{array}{l}\sum \mathrm{nd} \\
=2140\end{array}$ & \\
\hline
\end{tabular}

Table 7: Particle size distribution of formulation LIPO F 8006 (stirring speed 1000 rpm)

\begin{tabular}{|l|l|l|l|}
\hline Sr No. & Stability Conditions & Drug content (\%) & $\%$ CDR \\
\hline 1 & $2-8^{\circ} \mathrm{C}$ & $97.1 \%$ & $87.5 \%$ \\
\hline 2 & $25^{\circ} \mathrm{C} / 60 \% \mathrm{RH}$ & $92.2 \%$ & $83.1 \%$ \\
\hline 3 & $40^{\circ} \mathrm{C} / 75 \% \mathrm{RH}$ & $30.8 \%$ & $25.3 \%$ \\
\hline
\end{tabular}

Table 8: Drug content and amount of drug release of SLMs at different stability conditions. 


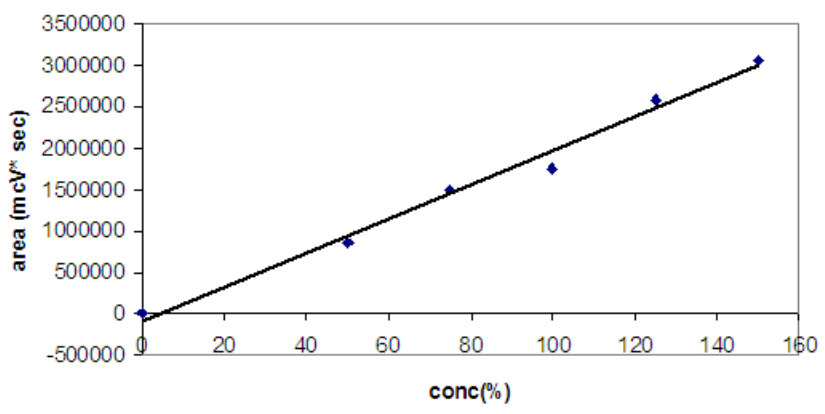

Figure 1: Linearity of sirolimus.

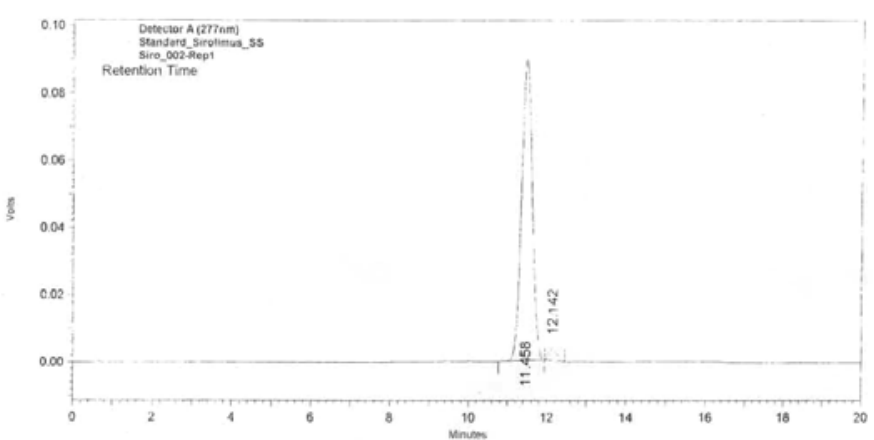

Figure 2: HPLC chromatogram of pure sirolimus

Release profile of sirolimus SLMs

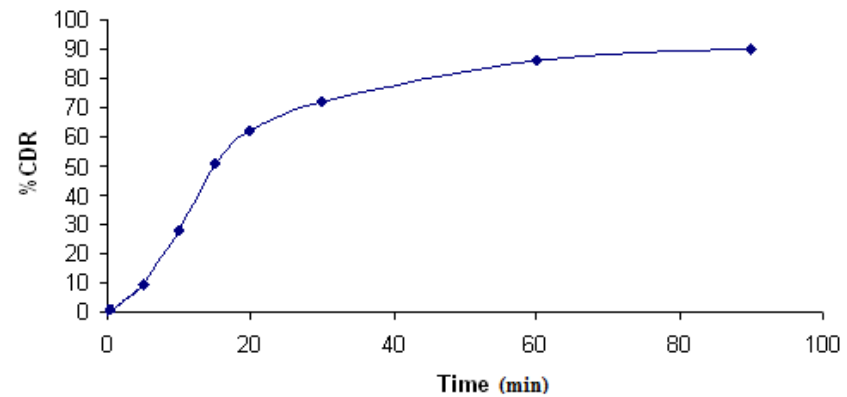

Figure 3: In vitro release profile of sirolimus solid lipid microspheres.

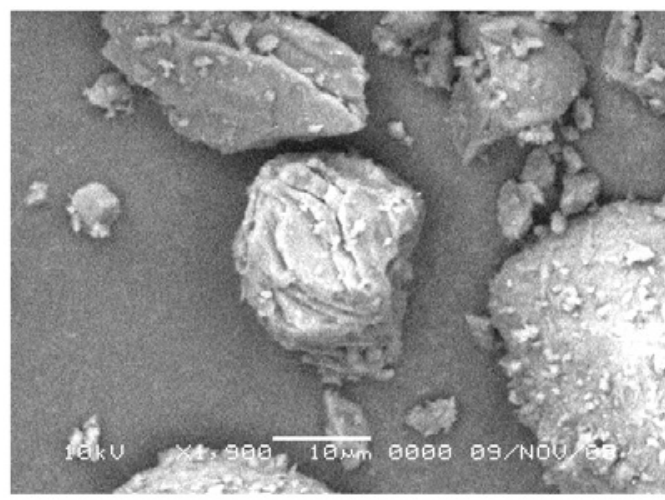

Figure 4: Scanning electron microscopy of sirolimus.

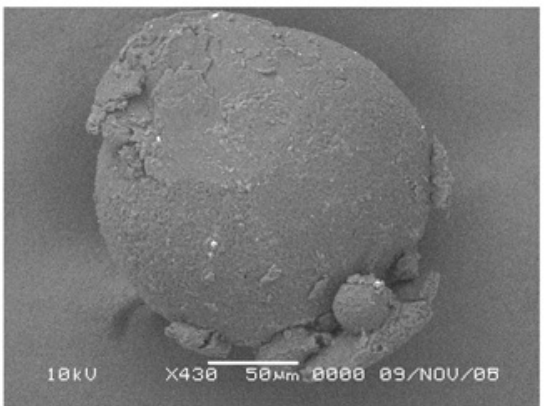

Figure 5: Scanning electron microscopy of SLMs of sirolimus.

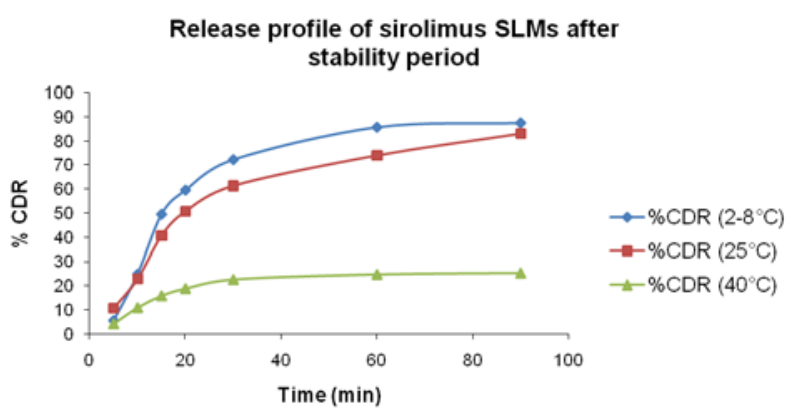

Figure 6: Release rate profile of sirolimus SLMs after stability period.

\section{Entrapment efficiency}

The entrapment efficiency ( at zero day) of the microparticles (Lipo F 8006), was found to be $98.02 \%$.

\section{In vitro dissolution study}

The dissolution study was carried out for the microspheres using $1 \mathrm{mg}$ equivalent of drug in $0.4 \%$ SLS as dissolution media. The composition of dissolution media is (400mg of sodium lauryl sulphate in $1000 \mathrm{ml}$ distilled water) and $\mathrm{pH}$ is 9 . The release profile of solid lipid microparticles is shown in Figure 3. Amount of drug released within 90 mins was found to be $90.3 \pm 0.58 \%(\mathrm{n}=3)$.

\section{Scanning electron microscopy}

Scanning electron microscopy (SEM) studies were carried out to observe the surface morphology. Scanning electron microscopy (SEM) studies were carried out for pure drug as well as SLMs of sirolimus. SEM picture revealed that the pure drug was somewhat spherical with rough surface while the Sirolimus SLM was smooth and spherical. (Figure 4, 5)

\section{Stability analysis of solid lipid sirolimus microsphere using HPLC}

A precise, sensitive, reproducible HPLC method of estimation for sirolimus in the formulations was developed. The analysis was carried out soon after preparation and after 30 days $\left(\right.$ at $2-8^{\circ} \mathrm{C}, 25^{\circ} \mathrm{C} / 60 \% \mathrm{RH}$ and $\left.40^{\circ} \mathrm{C} / 75 \% \mathrm{RH}\right)$. Drug content after the stability period found is reported in Table 8. Amount of drug release from the SLMs of sirolimus is also reported in the Table 8 and is graphically depicted in the Figure 6.

\section{Discussion}

In order to select the optimum formulation variables and to 
Citation: Nanjwade BK, Patel DJ, Parikh KA, Nanjwade VK, Manvi FV (2011) Development and Characterization of Solid-Lipid Microparticles of Highly Insoluble Drug Sirolimus. J Bioequiv Availab 3: 011-015. doi:10.4172/jbb.1000050

optimize the processing parameters, blank SLMs were prepared. Particle size analysis of blank SLMs shows that the optimum concentration of emulsifier (sodium taurocholate) to get the uniform sized microparticles is $0.2 \% \mathrm{w} / \mathrm{v}$. An increase or decrease in concentration leads to the crystal formation. Particle size may also get affected due to the homogenization speed and the stirring rate (Table 2,3). Particle size gets decreased as the stirring rate increases. The optimum stirring speed was found to be 1000rpm for 90 mins avoiding the crystal formation which is observed in case of the formulations with lower stirring rate and time.

SLMs were prepared by incorporating different amount (2.44g and $5 \mathrm{~g}$ ) of GMS. The higher amount of GMS showed satisfactory results. The higher drug content and entrapment efficiency with GMS is attributed to the high hydrophobicity resulting in increased accommodation of lipophilic drugs. Formulation Lipo F 8006 was subjected to in vitro release studies. The release study was performed in $0.4 \%$ SLS as dissolution media. The studies revealed that about $90.3 \%$ of drug released from sirolimus SLMs after 90 mins at zero day. In vitro release study shows SLMs shows immediate release of the drug. After stability studies at different conditions $\left(2-8^{\circ} \mathrm{C}, 25^{\circ} \mathrm{C} / 60 \% \mathrm{RH}, 40^{\circ} \mathrm{C} / 75 \% \mathrm{RH}\right)$ for thirty days, drug content and drug release profiles revealed that the formulations were most stable at $2-8^{\circ} \mathrm{C}$ and $25^{\circ} \mathrm{C} / 60 \% \mathrm{RH}$ but unstable at $40^{\circ} \mathrm{C} / 75 \% \mathrm{RH}$ (Table 8 ). Hence formulation should be kept at $2-8^{\circ} \mathrm{C}$ and $25^{\circ} \mathrm{C} / 60 \% \mathrm{RH}$ (cool and dry place). Presence of monoglyceride (GMS) may be responsible for the physical destabilization at higher temperature and humidity conditions. Lipids of less ordered crystal lattices such as GMS, though favored drug inclusion, were unstable due to the presence of monoglycerides.

\section{Conclusion}

Hot homogenization technique provides SLMs with higher drug content and entrapment efficiency by controlling the processing parameters. Hence, SLMs formulated with glyceryl monostearate and sodium taurocholate can be used for oral delivery of hydrophobic drugs with in-vivo study still to be explored.

\section{Acknowledgement}

The work has been supported by the KLE University, J.N. Medical College, Belgaum, Karnataka

\section{References}

1. Sehgal SN (2003) Sirolimus: Its discovery, biological properties, and mechanism of action. Transplant Proc. 35: 7S-14S.

2. Garber K (2001) Rapamycin's resurrection: A new way to target the cancer cell cycle. J Natl Cancer Inst 93: 1517-1519.

3. D.I. Pritchard (2005) Sourcing a chemical succession for cyclosporine from parasites and human pathogens. Drug Discov Today 10: 688-691.

4. Tsang CK, Qi H, Liu LF, Zheng XF (2007) Targeting mammalian target of rapamycin (mTOR) for health and diseases. Drug Discov Today 12: 112-124.

5. GK McEvoy (2002) AHFS drug information. 3706-3727.

6. Sanna V, Kirschvink N, Gustin P, Gavini E, Roland I, et al. (2003) Preparation and in vivo toxicity study of solid lipid microparticles as carrier for pulmonary administration. AAPS PharmSciTech 5: 1-7.

7. S. Jaspart, P. Bertholet, L. Delattre, B. Evrard (2005) Study of solid lipid microparticles as sustained release delivery system for pulmonary administration. 15th International Symposium on Microencapsulation, Italy

8. Dalpiaz A, Mezzena M, Scatturin A, Scalia S (2008) Solid lipid microparticles for the stability enhancement of the polar drug ${ }^{\mathrm{N} 6}$-cyclopentyladenosine. Int $J$ Pharm 355: 81-86

9. Zhang L, Liu L, Qian Y, Chen Y (2008) The effects of cryoprotectants on the freeze-drying of ibuprofen-loaded solid lipid microparticles (SLM). Eur J Pharm Biopharm 69: 750-759.

10. Dharmala K, Yoo JW, Lee CH (2008) Development of Chitosan-SLN Microparticles for chemotherapy: In vitro approach through efflux-transporter modulation. J Control Release 131: 190-197.

11. Hou D, Xie C, Huang K, Zhu C (2003) The production and characteristics of solid lipid nanoparticles (SLNs). Biomaterials 24: 1781-1785.

12. Reithmeier H, Herrmann J, Göpferich A (2001) Development and characterization of lipid microparticles as a drug carrier for somatostatin. Int $J$ Pharm 218: 133-143.

13. Reithmeier H, Herrmann J, Göpferich A (2001) Lipid microparticles as parentera controlled release device for peptides. J Control Release 73: 339-350.

14. Kumar VV, Chandrasekar D, Ramakrishna S, Kishan V, Rao YM, et al. (2006) Development and evaluation of nitrendipine loaded solid lipid nanoparticles: Influence of wax and glyceride lipids on plasma pharmacokinetics. Int J Pharm 30: $112-113$

15. Venkateswarlu V, Manjunath K (2004) Preparation, characterization and invitro release kinetics of clozapine solid lipid nanoparticles. J Control Release 95: 627-638. 